Sonja Mei Tin Huang*

ORCID: 0000-0001-9782-1566

New Taipei City, Tajwan

\title{
Pedagogia braterstwa Chiary Lubich z perspektywy azjatyckiej. Przykład akademickiego kursu ,Kultura Jedności” na Tajwanie
}

\author{
An Asian Perspective on Chiara Lubich \\ and her Pedagogy of Fraternity: \\ An Example of the Course "Culture of Unity" \\ in Higher Education in Taiwan
}

\begin{abstract}
Summary: As founder of the Focolare Movement, Chiara Lubich was greatly influenced by various fields and disciplines. Her thinking offers a platform of common ground for dialogue. The fundamental elements of Chiara's dialogue are the concepts of love and fraternity, which not only help the Catholic Church to have dialogue with other cultures and religions, but are also relevant to the academic world and our daily life. Chiara's thoughts on unity offer a fresh new perspective; once we have adapted our thinking to this, then a new kind of education becomes possible. Her spirituality of unity - introduced to Asia in 1966 - has been influential despite the fact that most of the population are non-Christian. Recently, some Asian

* Dr Sonja Mei Tin Huang jest adiunktem oraz dyrektorem Monumenta Serica Sinological Research Center na Katolickim Uniwersytecie Fu Jen na Tajwanie. Adres: No.510, Zhonhzheng Rd. 242 Xinzhuang, New Taipei City, Taiwan, R.O.C. Fu Jen Catholic University; e-mail: 043726@mail.fju.edu.tw.
\end{abstract}


scholars have been exploring new approaches using Chiara's philosophy to inform their research methodology and teaching; in Taiwan, the "Culture of Unity" course has experimented with new educational techniques influenced by Chiara's thinking. This paper aims to examine Chiara's thoughts on education, as well as her influence on higher education in Taiwan.

Keywords: Chiara Lubich; Pedagogy of Fraternity; Culture of Unity; Chiara and Asia.

Streszczenie: Chiara Lubich jako założycielka Ruchu Focolari miała ogromny wpływ na kształtowanie się różnych sfer życia i dyscyplin naukowych. Jej myśl stanowi platformę oraz wspólny grunt dla dialogu. Według niej podstawą porozumienia jest miłość i wspólnota, które nie tylko ułatwiają Kościołowi katolickiemu podejmowanie dialogu z innymi kulturami i religiami, lecz również oddziałują na świat akademicki oraz nasze życie codzienne. Spojrzenie Lubich na jedność podpowiada drogę odnowy naszego sposobu myślenia. Odnowienie sposobu myślenia jest początkiem procesu edukacyjnego. Jej duchowość jedności dotarła do Azji w 1966 r. W Azji, gdzie chrześcijaństwo dla większości ludzi jest religią obcą, jej ideał ma szczególnie ważne znaczenie i wpływa na tworzenie jedności między ludźmi. W ostatnich latach azjatyccy naukowcy starają się popularyzować myśl Lubich jako nowy rodzaj metodologii na polu badań i nauczania. Kurs „Kultura jedności” bazujący na myśli mistyczki został zaproponowany na Tajwanie jako sposób rozpowszechniania nowych możliwości edukacyjnych. Ten artykuł ma na celu zbadanie spojrzenia Lubich na edukację oraz jej wpływu na szkolnictwo wyższe na Tajwanie.

Słowa kluczowe: Chiara Lubich; pedagogia braterstwa; kultura jedności; Lubich i Azja.

Istnieje niewiele artykułów naukowych na temat wpływu Chiary Lubich na pedagogikę w Azji ${ }^{1}$. W 2013 r. podczas konferencji ,Patterns of Unity: An Interdisciplinary Dialogue on the Thought of Chiara Lubich (1920-2008)"

${ }^{1}$ Chiara Lubich (1920-2008) była założycielką Ruchu Focolari, urodziła się w Trydencie we Włoszech. Przeżyła II wojnę światową, w tym czasie zrozumiała, że nic nie jest wieczne, tylko miłość Boga trwa wiecznie. Ewangelia może poprowadzić ludzi ku szczęśliwemu życiu pełnemu radości. Miłość może przyciągać ludzi ku sobie, tworzyć przestrzeń do współpracy i dialogu. 
[„,Wzory jedności: interdyscyplinarny dialog na temat myśli Chiary Lubich (1920-2008)"] zostały zaprezentowane trzy artykuły. Pierwszy, napisany przez Thomasa Mastersa, to „Re-Imagining Education through a Spirituality of Communion” [„Przeobrażenie edukacji poprzez Duchowość Komunii”]; drugi nosił tytuł „Chiara and Life Education in Taiwan” [„Chiara i edukacja całożyciowa na Tajwanie”], ostatni zaś „Searching for Excellency is Striving for Love” [„Poszukiwanie doskonałości jest walką o miłość”]2. Wszystkie trzy teksty podejmowały tematykę zastosowania myśli Chiary Lubich w praktyce edukacyjnej. Pierwszy z nich, napisany przez Mastersa, prezentuje przykład, jak edukatorzy w Stanach Zjednoczonych przekładają teorie Lubich na grunt klasy szkolnej. Pozostałe dwa były powiązane z edukacją na Tajwanie, jednak stanowiły wyłącznie pewien rodzaj „hipotezy”. Oznacza to, że prezentujący uważali, iż duchowość Lubich może stanowić nowy wymiar szkolnictwa na Tajwanie, jednakże nie zostało to dotychczas sprawdzone w praktyce.

Niezależnie od tego, czy myśl Lubich ma wpływ na świat azjatycki, czy też nie, warto najpierw przyjrzeć się temu, w jaki sposób jej „,duchowość” może być ewentualnie powiązana $\mathrm{z}$ kulturami azjatyckimi. W tym artykule podjęte zostaną rozważania na temat duchowości Lubich oraz chińskiej kultury.

Od momentu pojawienia się duchowości Chiary Lubich w Azji w 1966 r. jej charyzmat jest atrakcyjny dla wielu mieszkańców ${ }^{3} n p$. Filipin, Tajwanu, Hong Kongu, Makau, Japonii, Korei, Chin, jak również innych państw południowo-wschodniej Azji ${ }^{4}$. Jej ideał kultury jedności od samego początku był akceptowany przez Azjatów, najpierw członków Kościoła katolickiego,

${ }^{2}$ Konferencja odbyła się na Katolickim Uniwersytecie Fu Jen na Tajwanie w 2013 r. Jej celem było odkrycie możliwego wpływu myśli Chiary Lubich na wiele obszarów, do których należą: teologia, edukacja, struktura komunikacji, dialog międzyreligijny oraz wpływ kultury jedności na środowisko, media, badanie kultury, translatoryka oraz psychologia [See: Sonja Mei Tin Huang, „The Report on the Conference Patterns of Unity: An Interdisciplinary Dialogue on the Thought of Chiara Lubich (1920-2008)", Catholic Weekly (Tienzhujiao Zhoubao 天主 教週報) 12 (28 April, 2013)].

${ }^{3}$ Dotyczy to osób, które stały się członkami stałymi lub współpracownikami Ruchu Focolari, jak również tych, które nie należą do ruchu, lecz biorą udział w corocznych letnich spotkaniach „Mariapolis”. Są to głównie katolicy, buddyści oraz osoby nieokreślające swojego wyznania. Charyzmat oznacza przydzieloną przez Boga władzę lub talent.

${ }^{4}$ Dotychczas nie powstała żadna oficjalna publikacja na temat historii Ruchu Focolari w Azji, lecz istnieją pojedyncze teksty naukowe o historii Ruchu Focolari w poszczególnych krajach azjatyckich. Na przykład w Encounter of Unity [Spotkanie Jedności] znaleźć można krótkie streszczenie historii Ruchu Focolari [see: Encounter of Unity (Heyi de Qiyu 合一的 奇遇) (H.K.: New City Press, 1955)]. Ponadto 14 marca 2015 r. odbyły się w Manili obchody 
a następnie również przez środowisko akademickie. Na Tajwanie w 1997 r., kiedy Chiara Lubich uzyskała tytuł doktora honoris causa w dziedzinie teologii na Katolickim Uniwersytecie Fu Jen, zauważalne stało się zaakceptowanie głoszonych przez nią idei przez lokalne Kościoły. Została określona jako „niezwykła kobieta i założycielka Ruchu Focolari, która miała ogromny wpływ na Kościół katolicki” w artykule „The Background and Meaning of Chiara Lubich's visit to Taiwan” [„Podłoże i znaczenie wizyty Chiary Lubich na Tajwanie"], napisanym przez wiceprezydenta Katolickiego Uniwersytetu Fu Jen, Louisa Gendrona SJ5. Gendron uważał, że ,jej duchowość: kultura jedności i dialog międzyreligijny były w pełni zgodne z założeniami Wydziału Teologii na uniwersytecie Fu Jen oraz z założeniami lokalnych Kościołów na Tajwanie" ${ }^{\text {. W }} 2013$ r. kilku członków Ruchu Focolori, którzy pracowali wówczas na różnych szczeblach akademickich na uniwersytetach na Tajwanie, zorganizowało konferencję: „Patterns of Unity: An Interdisciplinary Dialogue on the Thought of Chiara Lubich (1920-2008)" w celu zaprezentowania wpływu duchowości Chiary Lubich na środowisko akademickie oraz przedstawienia możliwości powiązania tejże $\mathrm{z}$ edukacją na Tajwanie.

Duchowość Lubich jest zgodna z kulturą azjatycką. Podczas swojego wystąpienia w UNESCO Lubich powiedziała: „Chrystus, syn swojego Ojca, Brat nas wszystkich, pozostawił nam uniwersalną wartość: wzajemną miłość. Wiedział, że właśnie ona jest konieczna do kształtowania pokoju i jedności na świecie, byśmy wszyscy stali się jedną, wielką rodziną" (wystąpienie Chiary Lubich podczas zgromadzenia UNESCO, 17.12.1996 r.) ${ }^{7}$,

50-lecia Ruchu Focolari w Azji, podczas których szczegółowo omówiona została historia ruchu [see: http://www.focolare.org/zh/news/2016/02/19/asia-50-anni-di-unita/; 5.06.2018].

5 Zob. Louis Gendron, „The Background and Meaning of Chiara Lubich's visit to Taiwan” (Lu Jiale laitai de beijing hen yiyi 盧嘉勒來台的背景和意義), Collectanea Theologica (Shenxue Lunji 神學論集) 111 (2017): 146.

${ }^{6}$ Tamże, 82. Wydział Teologii Katolickiego Uniwersytetu Fu Jen oddzielił się od uniwersytetu w 2011 r. Obecnie jest to niezależna uczelnia o nazwie Fu Jen Faculty of Theology of St. Robert Bellarmine.

${ }^{7}$ Zob. Chiara Lubich, Essential Writings (New York: New City Press, 2007), 14 (także we włoskiej wersji: Chiara Lubich, La Dottrina Spirituale (Milano: Mondadori, 2001), 55). Punkt widzenia Chiary został przedstawiony przez obecną prezydent Ruchu Focolari Marię Voce podczas jej przemówienia w Castel Gandolfo 12 marca 2016 r. Rozszerzyła ona ideę Chiary o „Chrześcijan różnych kościołów, wyznawców różnych religii oraz ludzi różnych kultur, którzy są motywowani chęcią stworzenia z ludzkości jednej, wielkiej rodziny” [zob. 
prezentując tym samym najbardziej fundamentalne dla człowieka wartości. Jej ideał jest zbliżony do cenionych przez Azjatów wartości, które stanowią rodzina, braterstwo oraz jedność. W myśli Lubich braterstwo jest podstawowym i kluczowym elementem tworzącym relacje oraz jedność pomiędzy ludźmi. Oprócz tego idea braterstwa istniała od zawsze wśród kultur azjatyckich, w których szczególne znaczenie przywiązuje się do kształtowania właściwych relacji rodzinnych i społecznych. Idea braterstwa w kulturze Chin wywodzi się z konfucjanizmu. Konfucjanizm był głównym nurtem myślowym w Azji, dlatego wywarł tak ogromny wpływ na tamtejsze kultury $^{8}$. Tradycyjny konfucjanizm zawiera ważną ideę, zbliżoną do koncepcji Lubich - ren (仁). Ren w konfucjanizmie definiowany jest jako dążenie znalezienia miejsca dla siebie, oznacza także wspieranie innych w odnajdywaniu życiowego powołania; ren może być określany jako pojęcie zbliżone do chrześcijańskiego miłosierdzia. Dla Chiary Lubich miłosierdzie oznaczało „miłość kierowaną do wszystkich”, ponieważ „Bóg nie prosi nas, byśmy miłowali jedynie biednych, lecz byśmy miłowali każdego bliźniego swego, jak siebie samego (Mt 19,19)"'. Konfucjusz postrzegał braterstwo jako niezwykle ważną wartość ${ }^{10}$. Istnieje powiedzenie, że „między czterema morzami wszyscy jesteśmy braćmi i siostrami”. Uczeń Konfucjusza, Mencius, podkreślał ogromne znaczenie międzyludzkiej miłości. Wartości podkreślane przez Konfucjusza oraz jego ucznia Menciusa są zbieżne z poglądami Lubich, zaczerpniętymi z Ewangelii: „miłuj bliźniego swego jak siebie samego" (Mt 19,19). Można znaleźć podobieństwa pomiędzy braterstwem

przemówienie Marii Voce na: http://www.focolare.org/en/news/2016/03/20/maria-voce-lacultura-del-dialogo-come-fattore-di-pace]. Maria Voce uważa, że Chiara Lubich zaproponowała metodę edukacji do pokoju, ,duchowość jedności”, która stanowi nowy sposób życia, mogący przezwyciężyć podziały między jednostkami.

${ }^{8}$ Wiele państw azjatyckich ma swoje korzenie w kulturze Chin, np. Wietnam, Japonia, Korea Południowa, Tajwan, Singapur, Malezja, Hong Kong, Makao itd. Wszystkie z tych krajów były mniej lub bardziej zależne od kulturowego i politycznego wpływu konfucjanizmu, buddyzmu i taoizmu, dlatego traktowane są jako część obszaru sino (świata konfucjanizmu, sfery kultury chińskiej) [zob. Li Xianhai, „From the Rising of Asian Value to the Contemporary Meaning of Confucianism", Academic Monthly 2 (2006): 53-54].

9 W Ewangelii według św. Mateusza, np. w rozdziałach 19 i 22, pojawiają się informacje o „miłości bliźniego swego jak siebie samego”.

${ }_{10} \mathrm{~W}$ starożytnych Chinach mówiono jedynie o braterstwie, ponieważ kobiety były zależne od mężczyzn. Jednakże to pojęcie powinno być obecnie rozpatrywane zarówno jako braterstwo, jak i siostrzeństwo. 
według Konfucjusza a ideą wspólnoty ${ }^{11}$. Z punktu widzenia Lubich dialog może stanowić pewnego rodzaju ścieżkę prowadzącą ku wspólnocie ${ }^{12}$. Dla Konfucjusza pomost prowadzący do wspólnoty jest zbudowany z cnoty, skromności oraz zachowania zgodnego z obrzędami kultury chińskiej ${ }^{13}$.

\section{Dialog w myśli Chiary Lubich}

Zagadnienie dialogu występuje zarówno w zachodniej, jak i chińskiej myśli filozoficznej, a sam dialog odgrywa kluczową rolę w komunikacji. W kulturze Zachodu dialog jest łączony głównie z obszarem filozofii. Może być rodzajem sporu na argumenty albo rodzajem narzędzia, „pozostawiając nietkniętym zadziwiający wymiar kształtowania charakteru"14. Spisane i wypowiedziane dialogi posiadają różne funkcje. Forma spisana jest „ciągle żywą formą literacką na przestrzeni historii filozofii”, która wprowadzana jest $\mathrm{w}$ relacji między dwiema osobami ${ }^{15}$. Dialog mówiony także ma wiele funkcji. Może być rodzajem instrukcji, środkiem „,rozstrzygania między opozycyjnymi stanowiskami, wymiany poglądów, rozwiązywania konkretnego problemu we współpracy z innymi, skłaniania innych do podjęcia decyzji”"16. Sokrates używał dialogu jako narzędzia dyskusji. Platon uważał dialog za niezależną formę literacką. Arystoteles podążał za jego wyjaśnieniami odnośnie do dialogu ${ }^{17}$. W starożytnych Chinach Konfucjusz używał głównie

11 Tradycja braterstwa została zaczerpnięta $z$ ideałów rewolucji francuskiej, a następnie wykorzystana przez Chiarę Lubich w znaczeniu chrześcijańskim.

12 Lubich, Essential, 359.

13 Zob. Confucius, „Yanyuan”, in: Chinese Text Projects, https://ctext.org/analects/yanyuan/. W tym rozdziale uczeń Konfucjusza, Yan Yuan, przedstawia dialog pomiędzy Si Ma Niu i Zixia na temat ścieżki prowadzącej ku braterstwu. Dialog brzmi następująco: Si Ma Niu, pełen niepokoju, rzekł: „Pozostali mają braci, tylko ja jestem samotny”. Zi Xia odpowiedział: „Istnieje następujące powiedzenie, które zasłyszałem - «Życie i śmierć pojawiają się w określonym momencie; bogactwa i honory zależą od niebios». Nigdy nie zawódź innych, bądź pełen szacunku wobec innych oraz bądź roztropny - wtedy wszyscy żyjący między czterema morzami staną się twymi braćmi. Dlaczego więc rozpaczasz z powodu braku braci?".

${ }^{14}$ Edmund Gross, „Dialogue”, w: Encyclopedia Britannica, t. 8, red. Hugh Chisholm (Cambridge University Press, 1911), 156-157.

15 See Karl L. van der Leeuw, ,Philosophical Dialogue and the Search for Truth”, Thinking: the Journal of Philosophy for Children 3 (2004): 2.

16 Tamże.

17 Sokrates i Platon używali obu form dialogu: mówionej i pisanej w różnych celach i funkcjach [zob. Leeuw, „Philosophical”, 2-3]. Kilku francuskich filozofów miało znaczący 
mówionej formy dialogu, aby uczyć swoich uczniów. Prowadził najpierw „instruktaż”, a jego słowa zostały spisane dopiero przez jego uczniów ${ }^{18}$.

Wywodząca się od Platona tradycja rozumienia dialogu ma duże znaczenie w XX w. Termin „dialog” używany jest nie tylko w filozofii, ale także w edukacji, życiu społecznym, kulturze, znajduje też zastosowanie w dziedzinie teologii. Dialog jest wykorzystywany w praktyce w różnych środowiskach. Wielu myślicieli rozwijało jego teorię, m.in. Mikhail Bakhtin czy Martin Buber. Uważa się, że „sformułowali holistyczną koncepcję dialogu jako wielowymiarowego, dynamicznego i zależnego od kontekstu procesu tworzenia znaczeń" 19 . Rewolucyjną rolę odegrała teoria dialogu Martina Bubera, ponieważ nie potraktował on dialogu jako „celowej próby wypracowania wniosków", jak to czynili ci filozofowie, którzy podążali za myślą Platona, ale wskazywał na prawdziwy dialog, który koncentruje się na autentycznej relacji między ludźmi, jak również między człowiekiem i Bogiem. Ten rodzaj prawdziwego dialogu posiada charakterystyczną otwartość, uczciwość i wzajemne zaangażowanie ${ }^{20}$.

Interpretacja dialogu zaproponowana przez Bubera otwiera nowy kierunek w myśleniu o sensie dialogu. Dialog nie musi być zawsze drogą do skłonienia innego człowieka, by przyjął pewnego rodzaju prawdy, ale może odnosić się do rzeczywistej współpracy, wzajemnej miłości i potencjalnej komunii między nimi.

Dialog w myśli Chiary Lubich zbliża się do idei dialogu, jaką wypracował Martin Buber, zawiera bowiem otwartość, wzajemną miłość i zaangażowanie. Mówiła ona:

wkład w powstanie teorii dialogu, np. Fontenelle (1683) i Nicolas Malebranche, który w 1688 r. opublikował książkę Dialogues on Metaphysics and Religion (Cambridge University Press, 1977); Mason Gross, Philosophy, Science and Higher Education (Piscataway: Transaction Publishers, 2002).

${ }^{18}$ Ustna forma dialogu prowadzonego przez Konfucjusza została przejrzyście zaprezentowana w jego Analektach (Lunyu 論語). Analekty prezentują procesy nauczania i uczenia się Konfucjusza poprzez jego dialogi z uczniami [Zob. Ma Shingyi (馬行誼), „Classic Annotation of Education in Confucian Analects" (Lunyu zhong de jingshi quanshi zhijiao 《論語》中的 經史詮釋之教), Journal of Language and Literary Education (Yuwen jiaoyu xuebao diyi qi 語文教育學報第一期) 1 (2013): 61].

19 Louise Phillips, The Promise of Dialogue: The dialogic turn in the production and communication of knowledge (Amsterdam: John Benjamins Publishing Company, 2011).

${ }^{20}$ Martin Buber, Between Man and Man (Eastford: Martino Fine Books, 2014), 129; Samuel Hugo Bergman, Dialogical Philosophy from Kierkegaard to Buber (New York: State University of New York Press, 1991), 219. 
Dialog jest terminem szczególnie pasującym do naszych czasów. Dialog oznacza, że ludzie spotykają się razem, i nawet jeżeli mają różne idee, mówią ze spokojem i autentyczną miłością do drugiej osoby, dążąc do wypracowania pewnego rodzaju zgody, która może wyjaśnić nieporozumienia, wyciszyć spory, rozwiązać konflikty, a nawet czasami wyeliminować nienawiść ${ }^{21}$.

Lubich traktowała dialog jako najważniejszą drogę do osiągnięcia jedności. Nawet między różnymi kulturami i religiami otwartość na dialog może uczynić nas zdolnymi „do całkowitego oczyszczenia się, tak że odsuniemy od naszego umysłu nasze idee, wszystko, co dla nas ważne, nasze uczucia, naszą wolę i wszystko, co chcemy uczynić, aby utożsamić się z drugą osobą"22. Co więcej, Chiara Lubich wspominała także myśli Jana Pawła II z książki Przekroczyć próg nadziei. Papież odnosił się w niej do drogi, którą kroczy się do osiągnięcia jedności, jaką jest pluralizm ${ }^{23}$. Dla Lubich drogą do osiągnięcia jedności między ludźmi jest wzajemna miłość ${ }^{4}$. To ona prowadzi do urzeczywistnienia jedności ${ }^{25}$. W jedności ludzie budują z kolei rzeczywistą i nową relację ${ }^{26}$.

Sformułowana przez Lubich idea dialogu została wprowadzona w życie najpierw między chrześcijanami. Miała ona nadzieję na budowanie duchowości ekumenicznej między Kościołami. Później Lubich uświadomiła sobie, że jedność i wzajemna miłość może łączyć wszystkich ludzi, którzy żyją tą duchowością, w jedno, niezależnie od ich kulturowych fundamentów ani religii, którą wyznają. Twierdziła: ,za sprawą tej duchowości ludzie będą zdolni do ofiarowania sobie świadectwa jedności, którą już osiągnęliśmy... jeżeli my, chrześcijanie, kochamy to, jak duchowość chrześcijańska uczy, możemy uzyskać większe światło, aby dostrzec i odkryć w innych religiach i kulturach ziarno Słowa" ${ }^{27}$. Chiara Lubich twierdziła, że religie i kultury niechrześcijańskie odbijają często promienie prawdy, którą objawił Chrystus, więc

21 Lubich, Essential, 340.

${ }^{22}$ Tamże, 240-341. Chara Lubich rozszerza swoją ideę dialogu na kontekst różnych religii, co jest charakterystyczne dla Ruchu Focolari.

${ }^{23}$ John Paul II, Crossing the Threshold of Hope (New York: Knopf, 1995), 167.

${ }^{24}$ Lubich, Essential, 328.

25 Tamże, 330.

26 Tamże, 338.

${ }^{27}$ Tamże, 331. Lubich przejęła tę myśl z dekretu Soboru Watykańskiego II Ad gentes, z rozdziału II: „Dzieło misyjne”, części 3: „Tworzenie społeczności chrześcijańskiej”, nr 15 [Zob. http://www.vatican.va/archive/hist_councils/ii_vatican_council/documents/vat-ii_decree_19651207_ad-gentes_en.html; 5.06.2018]. 
to odkrycie może zbliżyć nas do siebie i prowadzić do wzajemnego zrozumienia $^{28}$. Dialog, zgodnie z myślą Lubich, powinien być dialogiem na $360^{\circ}$, co oznacza, że powinien być rodzajem dialogu „dźwigającego wszystko"229. Jego zasadami są jedność, braterstwo i wzajemna miłość. W konsekwencji „duchowość komunii prowadzi na nową drogę życia”, która może budować jedność i braterstwo między nami ${ }^{30}$.

\section{Pedagogia braterstwa: nowa ścieżka w edukacji}

Chiara Lubich nie buduje samodzielnie teorii edukacyjnej. To, o czym mówi, dotyczy kluczowych kwestii odnoszących się do prowadzenia dialogu i budowania braterstwa między ludźmi, a także znaczenia jedności między chrześcijanami, różnymi kulturami i religiami. Oprócz tego w jej pismach odnajdujemy inną istotną ideę z punktu widzenia budowania jedności i braterstwa. Jest nią idea komunii. W jej mniemaniu obecność Jezusa w relacji pomiędzy przynajmniej dwiema osobami przynosi ducha komunii, a jedność jest zakorzeniona $\mathrm{w}$ komunii ${ }^{31}$. W jednym ze swoich wystąpień podczas katolickiej konferencji charyzmatycznej Lubich podjęła temat komunii ruchów kościelnych w trzecim millenium. W swojej przemowie odniosła się do znaczenia „czynienia Kościoła domem i szkołą komunii”32. Głęboko popierała ideę komunii, która została wyrażona przez papieża Jana Pawła II:

komunia (koinonia), będąca ucieleśnieniem i objawieniem samej istoty tajemnicy Kościoła. Komunia jest owocem i objawieniem owej miłości, która wypływając z serca przedwiecznego Ojca, rozlewa się w nas za sprawą Ducha darowanego nam przez Jezusa (por. Rz 5,5), abyśmy wszyscy stali się ,jednym duchem i jednym sercem" (por. Dz 4,32) (NMI 42) ${ }^{33}$.

${ }^{28}$ Sobór Watykański II, Deklaracja Nostra aetate, nr 2, http://www.vatican.va/archive/ hist_councils/ii_vatican_council/documents/vat-ii_decl_19651028_nostra-aetate_lt.html [5.06.2018].

${ }^{29}$ Idea i praktyka dialogu wypracowane przez Lubich zostały nazwane dialogiem $360^{\circ}$, co oznacza objęcie tym terminem dialogu z chrześcijanami różnych wyznań, ale także głęboką relację z wyznawcami innych religii i przedstawicielami innych kultur, ,czyli dialogu obejmującego partnerów o różnych rodzajach wierzeń” [Lubich, Essential, 320].

30 Tamże, 338.

${ }^{31}$ Chiara Lubich, Jesus in our midst (Manila: New City Press, 2003), 22-23.

32 Lubich, Essential, 320.

33 Tamże, 321. 
Lubich dowartościowuje ideę komunii w pięciu dialogach: z Kościołem katolickim, z Kościołami chrześcijańskimi, z innymi religiami, z osobami, które nie identyfikują się z żadną religią, oraz z innymi kulturami. Była przekonana, że zarówno te dialogi, jak i idea Ruchu Focolari są możliwe do zrealizowania „,w Bogu, wzór jest w niebie. Nawet w naszych najśmielszych przewidywaniach my nie jesteśmy w stanie wyobrazić sobie, że zobaczymy postępujące zbliżenie tych ludzi" ${ }^{34}$. Podążając za Bożą wolą, Lubich buduje jedność między chrześcijanami, różnymi kulturami i religiami. Podkreśla wartość jedności i braterstwa $\mathrm{w}$ tym świecie oraz to, że możliwe jest budowanie wspólnoty międzyludzkiej. Przez budowanie braterstwa ludzie są zdolni do życia w jedności, a przez to do doświadczenia oczyszczenia i uświęcenia ${ }^{35}$. Sformułowany przez Lubich sposób myślenia o wspólnocie, jedności i braterstwie ma wpływ na różne dziedziny wiedzy i życia: teologię, politykę, ekonomię, dialog międzyreligijny, sztukę i media, studia kulturowe itd. Posiada również znaczenie dla edukacji.

Istnieją naukowcy, którzy próbują odkrywać myśl Lubich w perspektywie jej znaczenia dla różnych dyscyplin. W odniesieniu do edukacji jest to wspomniany wyżej Thomas Masters, redaktor naczelny New City Press, autor artykułu: „In pursuit of Education's Highest Aim: Re-imagining Education through a Spirituality of Communion” [,,W dążeniu do najwyższego celu edukacji: przemyślenie edukacji z perspektywy duchowości komunii'] ${ }^{36}$, w którym wyjaśnia, jak można by udoskonalić edukację, odwołując się do duchowości Chiary Lubich. W swoim tekście wspomina o uformowanej w duchowości Ruchu Focolari nauczycielce, która starała się odpowiadać w swojej pracy na chaos, jakiego doświadczała w Ameryce. Owa nauczycielka myślała: „nie mogę nauczać, a uczniowie nie mogą uczyć się, dopóki nie osiągniemy wzajemności - co w konfucjanizmie mogłoby zostać

34 Tamże, 338.

35 Tamże, 37.

${ }^{36}$ Artykuł, który Thomas Masters zaprezentował na wspomnianej we wstępie międzynarodowej konferencji na temat myśli Chiary Lubich: „Patterns of Unity”, został opublikowany w książce wydanej w 2010 r. przez New City Press [Michael James, Thomas Masters, Amy Uelmen, Education's Highest Aim: Teaching and Learning through a Spirituality of Communion (New York: New City Press, 2010)]. Przekład tego artykułu na język chiński został ostatnio opublikowany w książce Patterns of Unity: An Interdisciplinary Dialogue on the Thought of Chiara Lubich (1920-2008), eds. Sonja Huang Mei Tin; Philipp HU Kungtze (Xinzhuang: Fu Jen Academia Catholica, 2018). Zebrano w niej 14 artykułów z takich dziedzin jak teologia, ekonomia komunii, psychologia, media, studia kulturowe, edukacja, inżynieria morska oraz studia translatorskie. 
nazwane relacjami «o ludzkim sercu»" ${ }^{37}$. Thomast Masters zgadza się z tym, co powiedziała wspomniana nauczycielka, że „owe relacje są fundamentem jedności w środowisku edukacyjnym"38.

Odnosząc się do edukacji w swoim przemówieniu wygłoszonym w Waszyngtonie podczas wręczenia honorowego doktoratu w dziedzinie edukacji, Chiara Lubich mówiła o dwóch fundamentalnych dla niej celach ${ }^{39}$. Należą do nich uczenie jednostki i budowanie wspólnoty ${ }^{40}$. Nawiązała tym samym do najważniejszej metody wykorzystywanej w edukacji. W jej opinii edukacja może być definiowana jako „droga, którą podmiot (pojedynczo lub jako wspólnota) kroczy z pomocą jednego lub więcej wychowawców, dążąc do celu uznanego za wartościowy zarówno dla jednostki, jak i dla ludzkości”41. Charakterystycznymi rysami metodyki pracy edukacyjnej, wynikającymi z duchowości, którą żyją członkowie Ruchu Focolari, są: Bóg jako Miłość, Słowo Boga i Jezus opuszczony ${ }^{42}$. Bóg jako Miłość, jako nasz ojciec, jest „wychowawca par excellence. On towarzyszy nam, odnawia nas i daje nam nowe życie"43. Słowo Boga znaczy: „ucz wszystkich wszystkiego"44. Jezus opuszczony to kolejne pojęcie wspominane przez Lubich. Wyjaśniała je w następujących słowach:

Jezus zawołał: „Boże mój, Boże mój, czemuś mnie opuścił?” (Mt 27,46) [...] On jest symbolem tych, którzy są ignorowani [...] symbolem tych wszystkich, którzy są najbardziej potrzebujący, nieprzystosowani, niesprawni; którzy są niekochani i zaniedbywani [...] Jednak Jezus opuszczony wyszedł poza swoje nieskończone cierpienie i modlił się: „Ojcze, w Twoje ręce powierzam ducha mojego" $\left(\right.$ Łk 23,46) ${ }^{45}$.

37 Zob. Thomas Masters, „In Pursuit of Education's Highest Aim: Re-imagining Education through a Spirituality of Communion”, Monthly Review of Philosophy and Culture 10 (2013): 121. Artykuł w języku chińskim w: Patterns of Unity: An Interdisciplinary Dialogue on the Thought of Chiara Lubich (1920-2008), eds. Sonja Mei Tin Huang, Philipp Kungtze Hu (Xinzhuang: Fu Jen Academia Catholica, 2018), 75.

38 Tamże.

39 To przemówienie zostało wygłoszone 10 listopada 2000 r. na Katolickim Uniwersytecie Ameryki w Washingtonie [See Lubich, Essential, 219].
40 Tamże, 223.
41 Tamże, 219.
42 Tamże, 219-221.
43 Tamże, 219.
44 Tamże, 220.
45 Tamże, 221-222. 
Lubich uważa, że figura Jezusa opuszczonego posiada znaczenie dla wychowawców. To ona wspiera ich, aby nie rezygnowali z ciągłego wypełniania swojej misji mimo trudności, które muszą ich spotkać. Lubich wspomina: „Jezus opuszczony jest naszą tajemnicą, naszą kluczową ideą, także w edukacji. On wskazuje na «ograniczenia bez ograniczeń», które powinny charakteryzować naszą edukacyjną pracę" ${ }^{\text {" }}$. Z tego względu należy „wychowywać do stawienia czoła trudnościom - co wiąże się z zaangażowaniem zarówno tego, który wychowuje, jak i tego, który jest wychowywany"47. Wszystkie metody, na które wskazuje Chiara Lubich, pokazują nową drogę dla wychowawcy: uczyć jednostkę oraz budować wspólnotę i jedność.

Co myśl Lubich może wnieść do współczesnej edukacji, a zwłaszcza do przestrzeni edukacyjnej w kontekście kultury chińskiej? Aby odpowiedzieć na to pytanie, należy wrócić najpierw do uwarunkowań edukacji w XX w. Warto zwrócić uwagę na ,salę lekcyjną, w której centrum umieszczano nauczyciela, ze zorganizowanym programem nauczania i uczniami pracującymi niezależnie, aby zapamiętać fakty. Nauczyciel działał jako «mędrzec na scenie», dawca wszelkiej wiedzy"48. Różnorodność uczniów i ich kreatywność były zazwyczaj ignorowane. Wielu teoretyków wychowania zauważało wady tej formy edukacji, dlatego starali się oni rozwijać alternatywne teorie edukacyjne, aby dostarczyć nowych pomysłów i sposobów udoskonalania warunków edukacji i jej jakości. Dla przykładu: Lew Wygotsky (1896-1934), rosyjski psycholog, miał znaczący wkład w budowanie nowej teorii świadomości, która odnosiła się do rozwoju „wyższych funkcji psychicznych”. Postrzegał rozwój psychiki człowieka jako „wynik związków interpersonalnych i aktywności w środowisku"49. Jego ujęcie sfery najbliższego rozwoju stało się kluczowym komponentem rozwoju nowego paradygmatu w psychologii rozwojowej i wychowawczej. Jean Piaget (1896-1980) był psychologiem i epistemologiem, którego największe osiągnięcie było związane z rozwojem dziecka. Położył podwaliny pod konstruktywistyczną teorię uczenia się, a szczególną uwagę przywiązywał do „schematu”, czyli wiedzy, którą dziecko już posiada, oraz sposobu, w jaki nowa wiedza może zostać powiązana z tym schematem ${ }^{50}$. Kolejne trzy teorie zostały sformułowane przez

${ }^{46}$ Tamże, 221.
${ }_{47}$ Tamże, 222.
${ }_{48}$ Zob. https://www.calvary.edu/comparison-20th-21st-century-education/. Uniwersytet w Calgary prowadził badania na temat różnic w edukacji szkolnej między XX a XXI w.

49 Zob. https://en.wikipedia.org/wiki/Lev_Vygotsky [11.04.2018].

${ }^{50}$ Zob. https://en.wikipedia.org/wiki/Jean_Piaget [11.04.2018]. 
Burrhusa Frederica Skinnera (1904-1990), Jerome'a Brunera (1915-2016) i Beniamina Blooma (1913-1999). Pierwszy był behawiorystą. Podkreślał, że pozytywne wzmocnienia utrwalają zachowania albo zwiększają pozytywne do nich nastawienie, tak że dobre zachowanie jest powtarzane ${ }^{51}$. Bruner zwrócił uwagę na spiralny program nauczania, przez co odniósł się do faktu, że dzieci mogą podejmować różne wyzwania na poziomie właściwym danemu wiekowi, i w związku z tym należy wracać do pewnych kwestii rok po roku, aby je pogłębiać ${ }^{52}$. Bloom zajmował się psychologią wychowawczą, przygotował klasyfikację celów edukacyjnych oraz sformułował teorię uczenia się, która rozpoczyna się od zdobywania wiedzy poprzez wzrost jej złożoności aż do ewaluacji53 ${ }^{3}$. Howard Gardner (ur. 1943) jest psychologiem rozwojowym znanym ze względu na teorię wielorakiej inteligencji. Głosi, że „konwencjonalna koncepcja inteligencji była zbyt wąska i restrykcyjna oraz że mierzenie IQ prowadzi do przeoczenia innych «inteligencji», którymi jednostka może dysponować" ${ }^{54}$. Warto jeszcze wspomnieć o katolickiej filozofii Jacques'a Maritaina (1882-1973), który poświęcił wiele uwagi edukacji. Jest najbardziej znany ze swojego ujęcia natury edukacji. Jego najważniejsza praca na temat edukacji: Wychowanie na rozdrożu [Education at the Crossroads (1942)], odnosi się do edukacji ku wolności, nazywanej liberal education. W jego opinii celem edukacji jest prowadzenie osoby ku temu, by stała się tym, kim jest. Uważał, że między uczniami występuje pewien rodzaj dynamizmu. Mogą uczyć się od siebie nawzajem, a nauczyciel nie musi odgrywać głównej roli w tym procesie - mogą ją przejąć sami uczniowie. W towarzystwie nauczyciela uczniowie mogą sami kierować procesem uczenia się ${ }^{55}$. Wspomniane powyżej teorie edukacyjne odnoszą się głównie do kształcenia ucznia, tak aby stał się dojrzały i niezależny w swoim myśleniu ${ }^{56}$. Należy jednak zauważyć, że podstawowymi wartościami, które zgodnie z tymi teoriami - wychowawcy mają rozwijać u swoich uczniów, są wolność i indywidualność.

${ }^{51}$ Zob. https://elearninginfographics.com/6-education-theorists-teachers-know-infographic/ [11.04.2018].

52 Tamże.

53 Tamże.

${ }^{54}$ Zob. https://www.verywellmind.com/howard-gardner-biography-2795511 [10.09. 2018].

${ }_{55}$ Zob. Jacques Maritain, Education at the Crossroads (New Haven: Yale University Press, 1966).

${ }^{56}$ Można by wskazać dużo więcej rozwijanych współcześnie teorii edukacyjnych, jednak wspomniano o najbardziej reprezentatywnych. 
W XXI w. edukacja ulega przemianom przede wszystkim ze względu na szybkie zmiany społeczne, technologiczne, kulturowe, a także proces globalizacji. Odchodzi się od edukacji skoncentrowanej na nauczycielu, na scenę wkroczył model, w którym centralne miejsce zajmuje uczeń. Nauczyciel przyjmuje rolę facylitatora ${ }^{57}$. Jego głównym zadaniem nie jest kontrola ani uczenie, ale przewodnictwo. Oznacza to, ze system edukacyjny musi być bardziej otwarty niż wcześniej ${ }^{58}$.

Jak bardzo otwarty mysi być to system i na czym polega kryzys edukacji w XXI w.? Główne Biuro Regionalne UNESCO zaznacza, że XXI w. przyniósł nowe dylematy dla edukacji. Z perspektywy edukacji przemiany we współczesnym świecie mają pozytywne i negatywne strony. Pozytywnym aspektem są „eksplozja wiedzy, zauważalny postęp w nauce i technologii [...] negatywną stronę tworzą problemy związane $\mathrm{z}$ moralnymi zagrożeniami człowieczeństwa, takimi jak zastosowanie technologii do celów destrukcyjnych, zniszczenie środowiska przyrodniczego i kryzys wartości"s9. Wskazania Głównego Biura Regionalnego UNESCO odnoszą się de facto do zjawisk, z którymi stykamy się współcześnie zarówno w społeczeństwie, jak i w edukacji. Technologia umożliwia rozwój, a równocześnie tworzy dystans w relacjach międzyludzkich. Wraz z rozwojem systemów edukacyjnych studenci są coraz bardziej niezależni i coraz bardziej dbają o swoją indywidualność, ale trudności sprawia im skupienie uwagi na kimś, kto jest obok nich. Rozwój zaawansowanych technologii i globalizacja prowadzą świat ku innym wartościom. Indywidualizm, materializm i relatywizm oddalają ludzi od siebie.

Ta relacja budowana przez nowoczesne technologie jest pozbawiona fundamentalnych elementów braterstwa - miłości i dialogu. Jak rozwiązać te problemy? Idee Lubich mogą być uznane za ważną alternatywę, która może zostać wprowadzona do szkolnej klasy ze względu na to, że docenia znaczenie braterstwa, dialogu i jedności pozwalające rozwijać zarówno życie społeczne, jak i samą edukację. Zadaniem edukacji nie jest tylko nauczanie dojrzewających osób, jak stać się dojrzałymi jednostkami, ale także podjęcie próby pomocy im w budowaniu wzajemnych relacji z innymi. Jeżeli uczniowie darzą się wzajemnym zaufaniem, współpracują ze sobą, wówczas różne

${ }^{57}$ Zob. https://www.verywellmind.com/howard-gardner-biography-2795511 [10.09. 2018].

${ }^{58}$ Zob. Raja Roy Singh, Education for the twenty-first Century: Asia Pacific Perspectives (Bangkok: UNESCO Principal Regional Office, 1991), I.

59 Tamże, IX. 
talenty, jakimi dysponują, sprawiają, że potrafią pomagać sobie nawzajem w stawaniu się osobami z całościową wizją własnego życia. Budowane między nimi braterstwo i jedność będą miały wpływ na ich życie. Omawiana tutaj idea edukacji może być dobrym sposobem przeciwdziałania indywidualizmowi we współczesnym świecie. Mimo że Chiara Lubich mówi o braterstwie, jedności i miłości, nie używa jednak dosłownie terminu ,pedagogia braterstwa". W jaki zatem sposób jej ideał może zostać rozszerzony tak, aby stworzył nowe możliwości terminologiczne i model pedagogicznej teorii? Istnieją dwa przykłady odnoszące się do tej kwestii.

W południowych Włoszech Lubich została patronką jednego z przedszkoli, ponieważ żywiono nadzieję na wykorzystanie pedagogii braterstwa i miłości w pracy z najmłodszymi. Psycholog Ezio Aceti traktował Lubich jako doskonałego wychowawcę. Jego decyzja, aby nadać tej placówce imię Chiary Lubich, została podjęta z nadzieją, że ,prowadzona w niej edukacja będzie inspirowana przez wartość braterstwa, która znajdzie wyraz w metodyce wychowania i przekazywania wiedzy przedmiotowej najmłodszym" Dla niego doskonałym przykładem takiego działania jest Lubich. Pójście za jej wzorem pozwala wychowawcy być świadomym wartości Ewangelii oraz aktywnie pomagać uczniom w budowaniu braterstwa we wspólnocie. Według Acetiego duchowość Chiary jest ,ciągle aktualna i nie przemija, nawet gdy założycielka Ruchu nie jest już z nami" ${ }^{61}$. Innym przykładem jest Instytut Uniwersytecki Sophia, który został założony w 2007 r. w Loppiano we Włoszech przez Ruch Focolari. Instytut oferuje studia magisterskie w zakresie fundamentów i perspektyw kultury jedności oraz korespondencyjną szkołę doktorską. Instytut rozumie ,siebie jako wspólnotę szkolenia się,

${ }^{60}$ Zob. http://www.focolare.org/en/news/2014/02/18/scuola-dellinfanzia-intitolata-a-chiara-lubich/ [12.04.2018]. Na tej stronie odnaleźć można całą historię nadania szkole imienia Chiary Lubich. Aceti wspomina tam także o innych osobach, które wiedziały, jak wprowadzać w edukacji nowy styl działania, jak chociażby: Simone Weil, francuska filozof, która wskazała na konieczność poświęcenia szczególnej uwagi jako „formy miłości do sąsiada, który w danym momencie wypowiada się". Aceti odwoływał się także do Martina Bubera jako tego, który „nawoływał do postawienia się na miejscu drugiego, do słuchania i podążania za inspiracjami, które z tego wynikają, i wreszcie do przekazania ich innej osobie". Kolejna inspiracja związana była z włoską pedagog Marią Montessori, która wypracowała system nauczania pokazujący, że ,jeśli możliwe jest nauczenie czegoś dziecka z niepełnosprawnością, możliwe jest nauczenie tego wszystkich dzieci”. Znaczący był dla niego wreszcie przykład Janusza Korczaka, polskiego wychowawcy, który towarzyszył dzieciom z sierocińca aż do momentu ich śmierci w obozie koncentracyjnym.

61 Tamże. 
uczenia i badań, w której uczestniczy się poprzez ćwiczenie adekwatnych umiejętności oraz wykonywanie obowiązków - kadra naukowa, studenci i personel" ${ }^{12}$. Każdy ze studentów jest w żywej relacji z innymi, doceniając to, co jest wartościowe w innych metodach działania, oraz zbliżając się do siebie nawzajem, a także szukając jedności między różnymi typami wiedzy w celu zbudowania nowego i bardziej integralnego obrazu świata ${ }^{63}$. W Instytucie Uniwersyteckim Sophia kultywuje się w przestrzeni edukacyjnej ideał Lubich: „Być rodziną... kochać siebie nawzajem aż wszyscy staną się jednością". Przywołane tutaj przykłady przedszkola oraz uniwersytetu wskazują na możliwość budowania na nowy sposób środowiska edukacyjnego. Lubich inspiruje zatem do tworzenia nowych możliwości w edukacji ${ }^{64}$. Ten rodzaj kształcenia skupia się na wzajemnej miłości i relacjach między uczniami. Nie są one często omawiane w innych teoriach edukacyjnych oraz wprowadzane w praktykę edukacyjną.

Czy refleksja Chiary Lubich nad edukacją może zostać przeniesiona na praktykę edukacyjną w Azji? Na Tajwanie podjęto taką próbę. Pod wpływem inspiracji tą myślą w jednej z tamtejszych uczelni wyższych zaproponowano kurs o nazwie „Kultura jedności”, którego celem było przekazanie studentom idei jedności i braterstwa. Studium tego przypadku pokaże, jak można posługiwać się pedagogią braterstwa i jaki rodzaj efektów może to przynieść w środowisku azjatyckim.

\section{Kurs ,Kultura jedności” w edukacji akademickiej na Tajwanie ${ }^{65}$}

Jak to zostało wspomniane powyżej, idee Chiary Lubich wykazują podobieństwo do wartości chińskiej kultury, spośród których jedność i brater-

${ }^{62}$ See: http://www.focolare.org/en/works-and-activities/studio-e-formazione/istituto-universitario-sophia/ [12.04.2018]. Instytut Uniwersytecki Sophia został erygowany przez Stolicę Apostolską dekretem Kongregacji Wychowania Katolickiego w dniu 7 grudnia 2007 r. Jest położony w Loppiano we Włoszech. Wydział obejmuje 30 profesorów uniwersyteckich z różnych krajów oraz ekspertów w różnych dyscyplinach: teologii, filozofii, etyki, prawa, nauk politycznych, ekonomii, językoznawstwa, literatury, nauk przyrodniczych, matematyki, komunikacji społecznej, sztuk pięknych, ekumenizmu i dialogu międzyreligijnego.

${ }^{63}$ Tamże.

${ }^{64}$ Nie ma obecnie zbyt wielu instytucji edukacyjnych inspirujących się duchowością Chiary Lubich.

${ }^{65}$ Kurs „Kultura jedności” został zaproponowany przez autorkę artykułu. 
stwo są szczególnie cenione przez osoby w niej wychowane. Czy jednak promowana przez Chiarę Lubich idea kultury jedności może być wprowadzona do sali szkolnej w kontekście kultury azjatyckiej, zostać zaakceptowana przez studentów, a ponadto skłaniać ich do tego, by spojrzeli na swoje życie z innej perspektywy? Było to wyzwanie, które nigdy wcześniej nie zostało podjęte na uniwersytecie, w którym większość studentów nie znała Chiary Lubich oraz Ruchu Focolari. Kurs pod nazwą „Kultura jedności”, oparty na duchowości Chiary Lubich, został zorganizowany w 2017 r. na Katolickim Uniwersytecie Fu Jen na Tajwanie. Propozycja ta została wysunięta z nadzieją, że młodzi ludzie z Tajwanu są świadomi wagi jedności i braterstwa. Oczekiwano, że - po zapoznaniu się z ideą jedności - mogą oni uczynić ją przedmiotem praktyki edukacyjnej oraz ich codziennego życia.

W rzeczywistości zaproponowanie przez uniwersytet kursu, który jest traktowany jako promocja katolickiej duchowości, nie było proste. Chociaż Uniwersytet Fu Jen jest uniwersytetem katolickim i zwraca szczególną uwagę na zagadnienia duchowości, to strona uniwersytecka stara się dyskretnie ingerować w programy organizowane na każdym z wydziałów. Kurs miał uzupełnić ofertę Wydziału Studiów Religijnych. Wszystkie kursy organizowane na wydziale muszą uzyskać aprobatę komitetu programowego, którego członkami są głównie niechrześcijanie. Kurs uzyskał zgodę na włączenie do oferty edukacyjnej Wydziału Studiów Religijnych w 2017 r. i zaczął być prowadzony we wrześniu 2017 r. przez 18 tygodni - jako kurs semestralny. $\mathrm{W}$ tygodniu realizowano dwie godziny dydaktyczne. Studenci byli w wieku 21-70 lat ${ }^{66}$. W ramach przygotowania kursu trzeba było wziąc pod uwage kilka trudności i wyzwań. Jednym z nich było religijne zaplecze studentów. Przykładowo w niereligijnym z założenia kursie powinno się unikać korzystania $\mathrm{z}$ katolickiego katechizmu. Jako niewłaściwe traktowane jest również, gdy nauczyciele przekazują doktrynę konkretnej religii albo promują określoną wspólnotę religijną. Z tego względu kurs został zaprojektowany - po pierwsze - jako wprowadzenie idei jedności i braterstwa oraz omówienie ich relacji do różnych dyscyplin wiedzy, i po wtóre, jako przygotowanie studentów do wprowadzania tych dwóch idei w praktykę. Czyniono to w nadziei, że studenci są w stanie zrozumieć znaczenie kultury jedności w trakcie zajęć i przenieść ten ideał na ich życie domowe oraz zawodowe. Układ kursu był następujący:

${ }^{66}$ Kurs został przygotowany jako kurs semestralny. Jego uczestnikami było kilka osób, które ukończyły już 65 rok życia. Z tego względu można przyjąć, że droga osiągania jedności jest drogą dla każdego człowieka, niezależnie od wieku. 


\section{Program kursu ,Kultura jedności”}

Tydzień 1: Wprowadzenie.

Tydzień 2: Na czym polega kultura jedności?

Tydzień 3: Czy współcześnie potrzebujemy jedności?

Tydzień 4: Kultura jedności a ludzie młodzi.

Tydzień 5: Kultura jedności a sztuka.

Tydzień 6: Kultura jedności a różne religie, cz. 1.

Tydzień 7: Kultura jedności a różne religie, cz. 2.

Tydzień 8: Kultura jedności a ekonomia komunii, cz. 1.

Tydzień 9: Kultura jedności a ekonomia komunii, cz. 2.

Tydzień 10: Egzamin częściowy.

Tydzień 11: Kultura jedności a ochrona przyrody.

Tydzień 12: Kultura jedności a media.

Tydzień 13: Kultura jedności a różne kultury.

Tydzień 14: Warsztaty: jak wprowadzić w życie codzienne kulturę jedności i braterstwa?

Tydzień 15: Kultura jedności a edukacja.

Tydzień 16: Kultura jedności a kultura Chin - dyskusja.

Tydzień 17: Jedność i braterstwo jako działanie, cz. 1.

Tydzień 18: Jedność i braterstwo jako działanie, cz. 2 - raport końcowy.

Należy zaznaczyć, że osoba prowadząca kurs otrzymała formację w Ruchu Focolari. Ceni zatem duchowość Chiary Lubich oraz dąży do wprowadzenia jej w życie w swoim miejscu pracy. W jej opinii przebieg kursu w początkowym etapie nie był prosty, ponieważ studenci nie znali idei jedności i braterstwa, jak również nie mieli doświadczeń związanych z wprowadzaniem jej w życie. Z pewnością nie znali Chiary Lubich i jej myśli. Równocześnie, jako Azjaci, rozumieli znaczenie rodziny, ponieważ społeczeństwa Azji są zorientowane na rodzinę. $\mathrm{Z}$ tego względu nauczyciel poświęcił cztery tygodnie, aby pomóc studentom zrozumieć kluczową rolę miłości wzajemnej, jedności i braterstwa dla życia rodzinnego, a nawet dla funkcjonowania w grupie. Miał nadzieję, że uczestnicy kursu zaczną traktować siebie nawzajem jako rodzinę zarówno w sali, jak i poza nią. Aby pomóc przełożyć idee na praktykę, zorganizował kilka przedsięwzięć. Promowana przez Lubich idea jedności była omawiana w sali, a następnie dokonywano porównania między myślą Lubich na temat jedności oraz ideą jedności obecną w kulturze chińskiej, tak aby studenci mogli zrozumieć lepiej jej myśl przez pryzmat 
własnego zaplecza kulturowego ${ }^{67}$. Po czterech tygodniach zajęć studenci spróbowali podjąć dyskusję i praktykować wzajemną miłość w odniesieniu do swoich kolegów, dało się też zauważyć u nich pewną przemianę. Studenci, którzy rzadko uśmiechali się do kolegów z grupy, zaczęli się do nich uśmiechać i pozdrawiać. Mogli nie rozumieć głębszego sensu jedności i braterstwa, ale dostrzegali i doświadczali wzajemnej miłości między nimi. Lubili pokazywać palcem „1” (jedynka oznacza jedność) na znak wzajemnej miłości i jedności. Rozumieli, że bez względu na to, gdzie się znajdują, mogą pozostawać w relacji dzięki jedności i wzajemnej miłości. „Jedność” stała się ich wspólnym językiem.

Po czterech tygodniach kontynuowano wprowadzanie ideału jedności w odniesieniu do innych aspektów życia. W rzeczywistości studenci mogli nie rozumieć wszystkich aspektów jedności i ich relacji do różnych obszarów życia, ale byli zwolennikami idei jedności w relacji do innych religii, kultur, a także wybranych obszarów działania (przykładem jest EoC: Economy of Communion - Ekonomia Komunii). Studenci okazywali szczególne zainteresowanie ekonomią komunii, której idea zrodziła się po wizycie Lubich w Brazylii w $1991 \mathrm{r}$. Ekonomia komunii jest projektem zapoczątkowanym w nadziei, że „między nimi nie ma nikogo w potrzebie" ${ }^{98}$. Studenci byli zaskoczeni, że istnieje wiele żywych przedsięwzięć w „kulturze dawania”, które zrodziły się z ekonomii komunii, polegającej na oddawaniu trzeciej części swojego dochodu ubogim. Studenci okazywali duże zainteresowanie także w odniesieniu do tematu „dialog międzyreligijny a jedność”.

Zrozumienie i budowanie jedności $\mathrm{w}$ grupie nie było proste zarówno dla studentów, jak i dla nauczyciela. W dyskusjach często wyrażali pogląd, że niemożliwe jest zbudowanie jedności między nimi, między różnymi religiami i kulturami. Nie wierzyli także, że idea EoC może być praktykowana, ponieważ wielu ludziom dzielenie się swoimi dochodami z innymi sprawia trudność. Jednak w trakcie zajęć każdy student chciał dzielić się swoim

${ }^{67}$ W kulturze chińskiej istnieje także koncepcja jedności - jedności między istotami ludzkimi i niebem (天人合一), która jest często wspominana w starożytnej filozofii chińskiej.

${ }^{68}$ Zob. Lubich, Essential, 274-275. Zgodnie z ideą EoC zysk byłby wspólny: „Jedna część byłaby wykorzystana do tego samego celu, który był istotny dla pierwszych wspólnot chrześcijańskich - pomocy ubogim, zapewniając im potrzebne do życia środki, aż do momentu znalezienia przez nich pracy. Druga część, aby rozwinąć struktury wychowujące «nowych ludzi», to znaczy ludzi ukształtowanych i ożywionych przez miłość, zdolnych do przeżycia tego, co nazywamy «kulturą dawania». Ostatnia część byłaby oczywiście wykorzystana do rozwoju firmy" [tamże, 275]. 
doświadczeniem wprowadzania tej idei w życie, będąc głęboko przekonanym, że uczynienie tego jest bardzo trudne. Wszystko to oznacza, że studenci rozumieli, na czym polega jedność między ludźmi, i byli skłonni do budowania jej z tymi, których spotykają i z którymi chcą ją dzielić. Dzięki wprowadzeniom do zajęć i dyskusjom w klasie studenci zdobywali wiedzę, że budowanie jedności i braterstwa w każdym aspekcie codziennego życia jest możliwe. Aby wprowadzić do tematu jedności i ukazać jego związek z różnymi dziedzinami życia, zaproszono kilku członków Ruchu Focolari, aby zaprezentowali poszczególne aspekty jedności oraz ich możliwy wpływ na różne obszary życia. Na przykład jeden z gości podjął temat jedności i mediów, inny dzielił się swoimi doświadczeniami prowadzenia dialogu międzyreligijnego itp. Teoria i praktyka odgrywały w tym kursie równorzędną rolę. Zazwyczaj w trakcie zajęć podejmowano zagadnienie jednego z aspektów jedności, następnie przychodził czas na dyskusję i dzielenie się przemyśleniami, i w końcu wracano do idei lub teorii dla lepszego jej zrozumienia przez studentów.

Po egzaminie śródsemestralnym studenci coraz bardziej traktowali się wzajemnie jako bracia i siostry. Dzielili się swoimi doświadczeniami trudności związanych z wprowadzaniem jedności w życie w poprzednim tygodniu oraz motywowali siebie nawzajem do dalszego podejmowania tego wyzwania. Utrzymywali kontakt z kolegami z kursu i pomagali sobie wzajemnie. Było oczywiste, że między nimi było budowane braterstwo. W raportach końcowych odnosili się do zagadnień: jedności i ochrony przyrody, jedności i Ekonomii Komunii, jedności w ich rodzinach itp. Warto wspomnieć zwłaszcza o dwóch z nich. Student - osoba 45-letnia - przeżywał od dłuższego czasu problemy w relacji ze swoją żoną. Stwierdził, że zrozumiał w trakcie zajęć znaczenie jedności oraz drogę jej budowania, dlatego postanowił praktykować ją w swojej rodzinie. Był świadomy, że jedność jest fundamentem rodziny. Z tego względu uczynił pierwszy krok dotyczący miłości do swojej żony - przeprosił za wszystkie złe rzeczy, które uczynił i które raniły jego żonę. Po tej rozmowie ich relacje małżeńskie uległy poprawie, ponieważ zaczęli budować harmonię i jedność między sobą. Inna osoba miała gorsze relacje ze swoją matką i postanowiła podzielić się z nią ideałem jedności, o którym usłyszała na zajęciach, co doprowadziło do wspólnej decyzji o życiu jednością. Po przedstawieniu tych raportów wszyscy uczestnicy zajęć wyrazili radość z osiągnięć ich autorów i pokazali znany już znak „1”. Nie ulega wątpliwości, że ,prawdziwy dialog” między nimi i ich rodzinami został zainicjowany, ponieważ wprowadzili w życie swoich rodzin teorię, z którą zetknęli się w sali wykładowej. 


\section{Wnioski}

Aby właściwie ocenić omówiony powyżej kurs, wiele elementów powinno zostać uczynionych lepiej. Dla przykładu: teoria powinna być lepiej sprawdzona, a praktyka przeanalizowana bardziej szczegółowo. Czy idee Chiary Lubich mogłyby zostać uznane za nową teorię pedagogiczną, a konkretnie: pedagogię jedności? Mówiąc szczerze, duchowość Lubich pokazuje możliwą nową drogę dla edukacji. Aby jednak przekształcić jej idee w rodzaj „teorii”, należałoby zebrać i sprawdzić więcej danych, odnoszących się do rezultatów wprowadzania myśli Lubich w życie. Jeżeli chodzi o wspomniany powyżej kurs, rezultaty osiemnastotygodniowej pracy przerosły oczekiwania nauczyciela. Kurs został zaakceptowany przez studentów i wywarł na nich pozytywny wpływ. Większość studentów po zapoznaniu się z ideami jedności i braterstwa uczyniła je przedmiotem praktycznych działań zarówno w sali wykładowej, jak i poza nią, chociaż oni nadal praktycznie nie znają ani Chiary Lubich, ani Ruchu Focolari. Dowodzi to, że duchowość Lubich może być z jednej strony zaakceptowana oficjalnie i wprowadzona do klasy szkolnej, zwłaszcza do systemu edukacji akademickiej, z drugiej zaś może wywierać pozytywny wpływ na życie studentów. Jednosemestralny kurs jest zbyt krótki, aby poczynić pełną obserwację na temat tego, jaki wynik daje wprowadzanie idei Lubich do praktyki edukacyjnej. Jednak informacje przekazywane przez studentów wstępnie świadczą o sukcesie. Kurs ma zostać przeprowadzony ponownie we wrześniu 2019 r., ale większość studentów, którzy brali w nim udział w 2017 r., wybrała inny kurs prowadzony przez nauczyciela, który w drugim semestrze tamtego roku akademickiego przybliżał na zajęciach zagadnienie jedności. Kiedy nauczyciel zobaczył byłych studentów ponownie na swoich zajęciach, zadał im pytanie o powód wyboru prowadzonego przez niego kursu. Odpowiedzieli, że mieli nadzieję na ponowne doświadczenie atmosfery braterstwa i jedności, którą poznali w trakcie „Kultury jedności”, chociaż kolejny kurs nie odnosił się do tego tematu $^{69}$. Wynik był zatem zachęcający. Ideały Lubich pomogły studentom szkoły wyższej zwrócić większą uwagę na znaczenie dialogu i budowania jedności w codziennym życiu. Zauważyli, że są braćmi i siostrami i chcieli przywrócić jedność $\mathrm{w}$ ich życiu rodzinnym. Z odpowiedzi studentów można wywnioskować, że mieli nadzieję oraz potrzebę kochania i bycia kochanym.

${ }^{69}$ Kurs „Kultura jedności” odbywał się w pierwszym semestrze, w drugim semestrze nauczyciel prowadził kurs „Religious Images and Religious Miniature”. 
Można w tym miejscu odwołać się do słów Lubich: „Nie mielibyśmy żadnego znaczenia na świecie, gdybyśmy nie byli małym płomieniem tego nieskończonego ognia: miłości, która odpowiada na miłość"70.

Kurs „Kultura jedności” jest drogą do budowania jedności i braterstwa, co stało się jasne w jego trakcie. Czy oznacza to w takim razie, że wywiedziona $\mathrm{z}$ duchowości Lubich idea kształcenia pasuje do edukacji jako takiej? Z punktu widzenia rozwoju teorii edukacyjnych jest oczywiste, że kluczowe problemy w sferze zdobywania wiedzy zmieniają się od czasu do czasu. Biorąc pod uwagę przejście od strategii nauczania zorientowanej na nauczyciela w XX w. do strategii skupionej na uczniu w XXI w., możemy stwierdzić, że środowisko edukacyjne zmieniło się z zamkniętego na otwarte. Obecnie zwraca się uwagę na to, aby kierować ucznia w stronę otwartości i myślenia krytycznego, ponieważ prowadzi to do rozwoju indywidualności studenta. Zmieniają się społeczne uwarunkowania edukacji, strategie nauczania, sami studenci, a nauczyciele, którzy mierzą się z tymi zmianami, muszą wykazać się „refleksyjnością”, aby uwzględniając wszystkie te zmiany, zrealizować w klasie cele edukacyjne ${ }^{71}$. Co nauczyciele zamierzają osiągnąć w klasie? Odpowiedzi mogą być różne.

Zdajemy sobie sprawę, że współczesny świat przeżywa liczne kryzysy, przede wszystkim w sferze ekonomii, które wynikają z globalizacji, a także problemy środowiskowe oraz związane ze światem wartości ${ }^{72}$. Współczesnemu człowiekowi nie brakuje wiedzy, zaawansowanych technologii oraz ambicji do szukania fortuny. Edukacja nie ma nadziei na osiągnięcie tych celów. Oprócz poszukiwania wiedzy edukacja ponosi wciąż odpowiedzialność za ubogacanie człowieczeństwa w jego holistycznym wymiarze. Amerykańska filozof Martha Nussbaum wyjaśniła, że człowieczeństwo może być ubogacane przez rozwijanie trzech zdolności. Pierwszą z nich jest: ,zdolność do krytycznego badania samego siebie oraz własnej tradycji; drugą jest postrzeganie siebie jako istoty ludzkiej, która jest powiązana z wszystkimi innymi więzami trosk, a trzecią jest narracyjna wyobraźnia"73. To, co ona uznała za

${ }^{70}$ Zob. Crescencia C. Gabian, Dialoge, Light and Fire: Chiara Lubich and the Spirituality of Unity (Manila: University of Santo Thomas Publishing House, 2017), 7.

${ }^{71}$ Zob. Chee Choy, San Oo Pou, „Reflective thinking and the Teaching Practice: A Precursor for Incorporating Critical Thinking into the Classroom?", International Journal of Instruction 1 (2012): 168.

${ }^{72}$ Zob. Joseph Stiglitz, „The global crisis, social protection and job”, International Labour Review 1-2 (2009): 2.

${ }^{73}$ Martha C. Nussbaum, Cultivating Humanity: A Classical Defense of Reform in Liberal Education (Cambridge, Massachusetts and London: Harvard University Press, 1997), 9-10. 
drugą zdolność, jest w mojej opinii kluczowe dla współczesnej edukacji. W tym punkcie można dostrzec zbieżności z myślą Chiary Lubich. Oprócz tego założycielka Ruchu Focolari wskazuje metodę, jak to osiągnąć. W swojej przemowie „Co jest istotne dzisiaj” wskazuje na istotną rzecz, której oczekuje współczesne pokolenie, czyli na: „Boga-Miłość, wiarę w jego miłość, odpowiedź miłością na jego miłość, to są wielkie imperatywy dnia dzisiejszego... bez nich świat zostaje skierowany ku zagładzie, jak pociąg wyrzucony z torów"74. Autentyczny dialog i relacje będą budowane poprzez wzajemną miłość. Spojrzenie Chiary Lubich na ten problem oraz metody jego rozwiązywania różnią się od wielu współczesnych teorii edukacyjnych. Jej wizja edukacji jest połączona z wiarą chrześcijańską. Najlepszym nauczycielem dla niej jest Jezus. Dla Chiary edukacja polega na wypełnieniu słów wyrażonych w modlitwie Jezusa: „Aby wszyscy byli jedno”. „To na drodze takiej edukacji my jako jednostki i jako wspólnota stajemy się zdolni do spotkania, wejścia w dialog i współpracy z innymi osobami, innymi ruchami"75. To, co powiedziała Chiara, sięga głębi jej chrześcijańskiej wiary. Dla studentów wywodzących się z kultury chińskiej całkowite zrozumienie duchowości Chiary może nie być osiągalne. Jednak kluczowe kategorie, do których się odwołuje, czyli ,jedność”, „braterstwo”, „miłość” i „dialog”, są zrozumiałe w chińskiej kulturze, która posiada te same idee zakorzenione w konfucjanizmie. $Z$ tego też względu duchowość Chiary jest znacząca zarówno dla edukacji akademickiej na Tajwanie, jak i dla całej kultury azjatyckiej.

Budowanie braterstwa i jedności w sali wykładowej nie stanie się od razu główną kwestią edukacyjną. Kurs „Kultura jedności” może być jednak dobrym przygotowaniem dla uczniów i dla nauczycieli do doświadczenia czegoś, co edukacja może im przynieść. Wszystko to jest dopiero na początkowym etapie rozwoju. Aby rozwijać pedagogię braterstwa Chiary Lubich i wprowadzać ją w życie, potrzebujemy lepszej metodyki i modeli edukacyjnych. Być może nowe inspiracje przyjdą, kiedy rozpocznie się druga i trzecia edycja kursu. W najbliższej przyszłości zamierzamy podjąć pracę zespołową nad opracowaniem programu. Przede wszystkim wiemy jednak i aktualnie tego doświadczamy, że idea jedności Chiary Lubich i jej pedagogia braterstwa stanowią nową drogę dla edukacji.

Ttumaczenie: Jarosław Horowski, Mateusz Smieszek

\footnotetext{
${ }^{74}$ Lubich, Essential, 56.

75 Tamże, 224.
} 


\section{Bibliografia}

Bergman, Samuel Hugo. Dialogical Philosophy from Kierkegaard to Buber. New York: State University of New York Press, 1991.

Buber, Martin. Between Man and Man. Eastford: Martino Fine Books, 2014.

Choy, Chee, San Oo Pou. „Reflective thinking and the Teaching Practice: A Precursor for Incorporating Critical Thinking into the Classroom?". International Journal of Instruction 1 (2012): 167-182.

Flecha, Ramón. Sharing Words: Theory and Practice of Dialogue Learning. MD: Rowman and Little field, 2000.

Gabian, Crescencia C. Dialoge, Light and Fire: Chiara Lubich and the Spirituality of Unity. Manila: University of Santo Thomas Publishing House, 2017.

Gendron, Louis. „The Background and Meaning of Chiara Lubich's Visit to Taiwan” (Lu Jiale laitai de beijing hen Yiyi 盧嘉勒來台的背景和意義). Collectanea Theologica (Shenxue Lunji 神學論集) 111 (2017): 82, 146, 152.

Gross, Edmund. „Dialogue”. In: Encyclopedia Britannica, ed. Hugh Chisholm, vol. 8, 156-157. Cambridge University Press, 1911.

Gross, Mason. Philosophy, Science and Higher Education. Piscataway: Transaction Publishers, 2002.

Huang, Sonja Mei Tin. „,The Report on the Conference Patterns of Unity: An Interdisciplinary Dialogue on the Thought of Chiara Lubich (1920-2008)". Catholic Weekly (Tienzhujiao Zhoubao 天主教週報) 12.28 April, 2013.

James, Michael, Thomas Masters, Amy Uelmen. Education's Highest Aim: Teaching and Learning through a Spirituality of Communion. New York: New City Press, 2010.

John Paul II. Crossing the Threshold of Hope. New York: Knopf, 1995.

Leeuw, Karl L. van der. „Philosophical Dialogue and the Search for Truth”. Thinking: the Journal of Philosophy for Children 3 (2004): 1-14.

Lubich, Chiara. Essential Writings: Spirituality Dialogue Culture. London: New City Press, 2007.

Lubich, Chiara. Jesus in our midst. Manila: New City Press, 2003.

Lubich, Chiara. La Dottrina Spirituale. Milano: Mondadori, 2001.

Malebranche, Nicolas. Dialogues on Metaphysics and Religion. Cambridge: Cambridge University Press, 1977.

Maritain, Jacques. Education at the Crossroads. New Haven: Yale University Press, 1966. 
Masters, Thomas. „In Pursuit of Education’s Highest Aim: Re-imagining Education through a Spirituality of Communion". Monthly Review of Philosophy and Culture 10 (2013): 121-137.

Nussbaum, Martha C. Cultivating Humanity: A Classical Defense of Reform in Liberal Education. Cambridge, Massachusetts and London: Harvard University Press, 1997.

Patterns of Unity: An Interdisciplinary Dialogue on the Thought of Chiara Lubich (1920-2008), eds. Sonja Huang Mei Tin, Philipp HU Kungtze. Xinzhuang: Fu Jen Academia Catholica, 2018.

Phillips, Louise. The Promise of Dialogue: The dialogic turn in the production and communication of knowledge. Amsterdam: John Benjamins Publishing Company, 2011.

Singh, Raja Roy. Education for the twenty-first Century: Asia Pacific Perspectives. Bangkok: UNESCO Principal Regional Office, 1991.

Stiglitz, Joseph. „The global crisis, social protection and job”. International Labour Review 1-2 (2009): 1-13.

Xianhai, Li. „From the Rising of Asian Value to the Contemporary Meaning of Confucianism". Academic Monthly 2 (2006): 53-58.

Xinyi, Ma. „Classic Annotation of Education in Confucian Analects”. Journal of Language and Literary Education 1 (2013): 59-76. 
